\title{
Institutional innovations in public participation for improved local governance and urban sustainability in India
}

Sanskriti Menon ${ }^{1,2^{*}}$ (1) and Janette Hartz-Karp ${ }^{1}$

\begin{abstract}
Background: Improving urban governance is an imperative for India, with its accelerated rate of urbanization, distrust of government, and inadequate public involvement in policy development and decision-making. Deliberative democracy initiatives in other parts of the world, and similar experiences in rural India have demonstrated their effectiveness at resolving complex issues with decisions that are acceptable to constituents, and are seen to be in the public good.

Results: Learnings are drawn from two cases of action research in Pune, India about achieving inclusion and deliberation in public engagement efforts, and their influence on public decision-making. The stratified and complex socio-economic and political context in India, power imbalances, inadequacy of decentralized governance structures, and information for civic decision-making makes public engagement challenging. From this experience, we inductively developed a potential framework for good governance, of deliberative democracy initiatives (induced participation), inclusive civil society (organic and invented) participation, overseen by an independent third party. It is contended that such a framework can enable city governments, in India and elsewhere, to resolve complex urban sustainability challenges with more implementable decisions.

Conclusions: Based on what was learnt from the Pune case studies, this article suggests that a combination of leaders willing to pioneer good governance, capable third-party facilitators, and strong organic participation groups working together through the structured approaches of deliberative democracy can effectively integrate the public into civic decision-making. However, to implement deliberative democracy in urban areas in India, the framework proposed will require advocacy at multiple levels. It will be critical to find 'champions' within political, administrative and civil society willing to pioneer deliberative democracy initiatives, to build professional capacity to conduct high quality deliberation, and to ensure the outcomes of such processes are influential. Good governance will rely on an ecosystem supporting such democratic renewal.
\end{abstract}

Keywords: Deliberative democracy, Good governance, Sustainability, Urban governance, Organic participation, Induced participation, Participatory budgeting, Street design, Third party facilitation

\footnotetext{
* Correspondence: sanskriti.menon@ceeindia.org

${ }^{1}$ Curtin University Sustainability Policy Institute, Curtin University, Perth,

Western Australia, Australia

${ }^{2}$ Centre for Environment Education, Pune, India
}

(c) The Author(s). 2019 Open Access This article is distributed under the terms of the Creative Commons Attribution 4.0 International License (http://creativecommons.org/licenses/by/4.0/), which permits unrestricted use, distribution, and reproduction in any medium, provided you give appropriate credit to the original author(s) and the source, provide a link to the Creative Commons license, and indicate if changes were made. The Creative Commons Public Domain Dedication waiver (http://creativecommons.org/publicdomain/zero/1.0/) applies to the data made available in this article, unless otherwise stated. 


\section{Introduction}

With rapid urbanization in India, a focus on good governance is critical for urban sustainability. Public participation is an important element of good governance. Using the results of an action research initiative, this article proposes a particular form of participation in governance in Indian cities to improve sustainability outcomes, that is Deliberative Democracy, which has been implemented successfully elsewhere in the world. Deliberative democracy is characterized by inclusivity, deliberative quality, and influence on decision-making.

According to Varshney (1989), India is sometimes called an 'unlikely democracy', built as it has been in 'poverty, widespread illiteracy, and a deeply hierarchical social structure' which are seen as 'inhospitable conditions for the functioning of democracy'. However, the focus of this paper is not to critique representative democracy or to suggest that deliberative democracy may fix the shortcomings of representative democracy. Rather, it is to consider deliberative democracy as an essential element of deepening democracy in the Indian context.

On the basis of an action research initiative in Pune, India, carried out over 2013 to 2018, we suggest that deliberative democracy may be introduced in urban public decision-making in India as a way of addressing sustainability challenges. In particular we suggest that deliberative democracy must build upon the strengths of the public participation experiences in India. Though its processes and methods would need to be contextualized, Deliberative Democracy may help to address some challenges in efforts to enhance public participation. Further, some of the characteristics of Indian society that make democratic engagement challenging, could in fact be surfaced and consciously addressed in the design of deliberations. Besides integrating the strengths and challenges of organic participation, Deliberative Democracy can also be one of the models to meet the institutional gaps in induced or government led participation in urban areas, with reference to the 74th Constitutional Amendment Act of India.

The article is organized in three sections. In the Background section, we suggest that deliberative democracy would build upon current participation processes, but first, we identify key strengths and challenges of organic or grassroots claimed spaces of participation. We also present some gaps in the institutional structures for participation in the urban context. Next, we briefly introduce deliberative democracy and the role of a third party. The second section presents our methodology and outlines the action research initiative. In the third section, we discuss the results of our research. We conclude with a summary of our findings and present some suggestions for the way forward.

\section{Background: Participation in urban governance}

India is rapidly urbanizing, with approximately 377 million or $32 \%$ of the population living in cities [1] and projected to be about 800 million and $50 \%$ of the population by 2046 [2]. The challenges of urban sustainability for India are immense, and effective decision-making - good governance, will be critical. Good governance here refers to decision-making that is participatory, inclusive (including the views of the disempowered), egalitarian, accountable and transparent, where corruption is minimized. In short, effective public participation - meaningfully involving the broad public in issues that matter - is key to good governance. UN Sustainable Development Goal 11 on sustainable cities and communities also incorporates enhancing capacity for 'participatory, integrated and sustainable human settlement planning and management' as a target. Public participation has instrumental value in improving democratic decision-making that supports sustainability $[3,4]$ as well as intrinsic value [5], and is recognized as a highly worthwhile endeavour [6-9]. It should be noted, however, that some authors have qualified such assertions in the case of highly stratified societies [10], or those characterized by corruption and patronage [11]. This is due to the danger of elite capture of participation processes and spaces, perpetuating inequity. Heller suggests that the exercise of citizenship can be subverted in societies where extraconstitutional forms of authority such as patriarchy and caste subordination over-ride public authority [12]. We come back to this thread in the discussion on organic participation later in this section.

Elections and universal adult suffrage are seen as a fundamental method of participation in representative democracies. Since Independence, India has had regular and relatively inclusive elections, separation of powers, an active and independent judiciary, apolitical military, and open press. On this basis, the country is said to be a successful, albeit an 'unlikely democracy' given poverty, illiteracy, socio-cultural diversity and deep structural inequity [13-15]. Varshney [14] also points out that "marginalized and oppressed groups are exercising their democratic rights to a degree that was unheard of in the 1950 s and 1960s". However, if democracy is judged according to broader effective governance measures, including meaningful participation of the people in governance, India's democratic success is questionable. The founders of the Indian Constitution seemed to adopt the spirit of collective deliberation and action as a core principle of Indian democracy. Dr. B R Ambedkar, the Chairman of the drafting committee of the Indian Constitution, held that:

"There should be varied and free points of contact with other modes of association. In other words, there must be social endosmosis. This is fraternity, which is only another name for democracy. Democracy is not 
merely a form of Government. It is primarily a mode of associated living, of conjoint communicated experience. It is essentially an attitude of respect and reverence towards fellowmen." [16] (p. 50).

However, this concept has not yet been realized in the everyday practice of democracy in India's cities. Though India does have a wealth of experience and long traditions of participation in governance in various forms, in the following discussion we show that there is a space in India for deepening democracy beyond the range of the current participation processes.

Mansuri and Rao (2013) [17] have characterized participation as 'organic' and 'induced'. 'Organic participation' includes social movements that fight for greater democratic expression and for the rights of the underprivileged, labour movements, unions, membership-based organizations to improve livelihoods and living standards (ibid). Others, like Miraftab [18] and Cornwall [19] describe the struggles of the poor as claimed, invented or insurgent spaces of participation. 'Induced participation' is 'promoted through policy actions of the state and implemented by bureaucracies, ... and comes in two forms: decentralization and communitydriven development' (Mansuri \& Rao). These are not cleanly divided processes or spaces, and have some strengths and present some challenges, discussed further in this section.

\section{Organic and claimed Participation}

Social movements, claimed participation spaces, including organic NGO-led participation, are a strong shaping force in India, surfacing important issues of social and environmental justice, entitlements and equity. They have thrown new light on different aspects of the human condition, and followed up with the authorities, through to the judicial system, to secure rights and justice. In recent years, a range of rights-based initiatives have led to legislation and substantive gains on crucial elements of human rights and well-being in India, such as on the right to education, right to information [20], the Domestic Violence Act [21], the Street Vendors Act, the securing of livelihoods of waste pickers [22], and shelter for the poor in Mumbai [23]. Advocacy groups can provoke civic interest in and attention to issues, and in doing so, provide fertile ground for public participation initiatives. For example, the Pune urban design deliberative democracy initiative, described later in this article, emanated from organic participation and advocacy. Similarly, referring to the experiences in Mendha Lekha village in eastern Maharashtra, Mohan Hirabhai Hiralal suggested that abhyas gats or study circles could be convened on topics that emerge as jivhalyachya prashna, - issues that people felt strongly about. These would be the issues people voluntarily spend time deliberating, precisely because of their strong feelings. Additionally, leaders of organic participation initiatives often, though not always, develop considerable expertise about the issues they raise. They can bring new knowledge to the table and new resolve to ensure decision-makers take this seriously.

Organic participation plays an influential role in reaffirming democracy in India, irrespective of the substantive or normative views involved, depth of understanding, or perspective - holistic or fragmented. It is a demonstration and reaffirmation of people's freedom of expression, the right to associate, and to raise issues of concern for examination, deliberation and action by the larger polity. Goswami \& Tandon (5) suggested that this is what makes Indian democracy alive and vibrant [21].

Although organic participation is an integral element of meaningful participation, alone it cannot bring about good governance. It has been said that democracy is better sustained when there are community networks and a social fabric of trust and cooperation [24], neighbourhood organizations [25], and a tradition of discussion in society [26]. People living in such a society may feel more readily able to voice topics of concern, and for the neighbourhood associations to take these concerns forward. However, these societal qualities can malfunction when there are prevailing deep-rooted structural inequities like the caste system, and divisions among socioeconomic classes. Hence, rather than cooperation, organically emerging issues have often tended to drive divisive behaviour, turning one group against another [27]. Such structural inequities prevent disempowered marginalized people from raising concerns organically [10]. Or, if they have been surfaced, the mostly elite groups responding have not listened and acted on them, or such concerns have been crowded out among issues raised by more vocal and powerful groups.

Inequities and exclusions may be exacerbated in certain types of elite-led participation [28, 29], while the poor are forced to access public services through political patronage [27]. While public resistance often supports more sustainable outcomes, in recent years in India, the nature of such resistance is changing, with middle-class and upper-class protestors becoming prominent, and the marginalized largely failing to make visible protests against decisions that affect them, exacerbating existing inequities [30]. Miraftab, highlighted that often planning and governance processes in the global South engage with certain types of community-based groups who are 'celebrated as civil society representatives' and invited into participatory processes while criminalizing and disengaging others from decision-making processes, who have to resort to insurgent practices to claim their rights and access to basic services [18].

For these reasons, and more generally in the interests of good governance, relying on organic participation or community bonds and associational life to achieve equity 
and sustainability is inadequate. Indeed, it could be said that both organic participation and elected government have distorted motivations (the former due to structural inequities, and the latter due to party political influences and the need to be re-elected).

\section{Induced Participation}

In India, the most consequential enablers of induced participation have been the 73rd and 74th Constitutional Amendment Acts (CAA), creating institutions of local self-government in villages and urban areas across the country, with elected councils. However, the elected councils or civic groups per se and the extent to which they deliberate is not the focus of this research, but rather whether the elected councils involve civic groups and the general public meaningfully in deliberation on difficult issues.

Much of the literature referring to empowered participatory governance in India refers to local self-government in rural India, especially in relation to gram sabhas (village assemblies). These include the well-known decentralized people's planning processes in Kerala [31, 32] and also in Maharashtra [33] and Mendha Lekha (Mohan Hirabhai Hiralal, oral communication, September 2016), including deliberative democracy processes. ${ }^{2}$

There are some efforts of induced participation in urban areas as well, such as participatory urban planning in Chhattisgarh, planning for street vending in Mumbai, for slums in Ahmedabad [34] and neighbourhood level and urban ward planning in Kerala [35]. An induced participatory method that has had success in reducing structural inequities is Participatory Budgeting (PB). PBs have now been implemented in around 3000 places across the globe [36]. A percentage of a government budget (usually around 10\%) is allocated to projects by those living and working in the area. Civic groups develop proposals which are broadly disseminated, and then community members vote on their preferences [37]. This process is particularly effective when it is codecisional (between the government and its constituents); and when it is supported by a mechanism to reduce inequity, e.g. an Index listing issues important to well-being, so during the budget prioritization process, additional weight can be given to those disadvantaged [38]. Though ideally, PBs foster more democratic and equitable decision-making, in Pune and elsewhere PBs are often more tokenistic than meaningful public participation. For example, in Pune, an independent review of the local PB process highlighted problems that it was inadequately co-decisional and unable to systematically address issues of inequity [39]. A deliberative initiative, described later in this article, developed recommendations to improve Pune's PB regarding both empowerment and equity, however they were not taken up by Pune's municipal government. Conversely, in areas with traditionally strong public participation, such as in Kerala and induced and externally supported participation in rural Maharashtra, specific processes are implemented to bolster empowerment and equity. For example, in both areas, a development report is made public prior to annual budgeting so the community is better informed about areas of strength and inequality.

Since the mid-90s, the Indian Government has promoted the formation of self-help groups (SHGs) for savings, credit and microenterprise activity, especially of urban poor women. In some cities these SHGs are also vehicles for prioritization of shortfalls in basic services provision in poor neighbourhoods and slums, and supervision of improvement projects [40]. Participatory micro-planning under Kerala's similar Kudumbashree programme nests within annual municipal planning. Overall inclusion and equity are variable, particularly in relation to local patterns of formal and informal political power, which may also reinforce exclusion of the poorest. Nonetheless, these programmes have been successful in enhancing the presence of women in participatory governance processes [41].

However, there are critical deficits in the institutional reforms of urban governance: limited implementation of decentralization under the 74th CAA [42], disjuncture between planning, governance and poverty alleviation [34], the poor ratio of representation, the lack of structures in urban areas analogous to the village gram sabha $[43,44]$, and limited functional and financial autonomy for municipal governments even if participatory processes are undertaken [35]. Public hearings are provided for as part of Environment Impact Assessment legislation so people can voice their views, though experience shows that such inputs have unclear influence on the decisions made [45]. As part of master plan preparation processes, the public may formally record objections and suggestions, but the decision-making processes do not incorporate opportunities for public participation to evolve combined thinking about the issue that could reflect common ground [46].

Critically, unlike the 73rd CAA that created gram sabhas in rural areas, the 74th CAA has not created a structure for direct democratic participation in cities. Ramanathan (2007), Founder of the non-profit Janaagraha [43] proposed that area sabhas be created in urban areas with every registered voter in a polling station as a member. Subsequently, under the Government of India's Jawaharlal Nehru National Urban Renewal Mission that was launched in 2006 (to which Ramanathan was a Technical Advisor), state governments were asked to include a provision for community participation as a pre-condition for receiving funding from 
the central government. A provision for area sabha was enacted by at least 12 states but none have constituted these [47].

Thus, there is a near absence of inclusive, egalitarian, well-informed, induced participation forums in urban areas in India. Governments rarely seek public participation in urban issues, other than to provide information, allow for grievances and hearings, and sometimes to seek opinions through surveys, workshops and consultations. The aim of such participation is to inform or consult (receive public feedback) and sometimes to involve (understand and consider public views), but rarely, if ever, to collaborate or empower [48]. While the struggles of the urban poor and other organic participation efforts have led to major gains, in the absence of structured forums of direct participation underpinned by public authority, societal inequities continue to pervade access to formal governance.

Then there is the disjunction between the formal and substantive aspects of citizenship in India, especially in cities. Desai \& Sanyal (2012) point out that the poorest are denied many of their fundamental rights in practice [49]. Luckham et al. [50] have described the distinction between democratic institutions and democratic politics. Democratic institutions are the formal structures and procedure of democracy, while democratic politics refers to the actual engagement of the public in decisionmaking. The levels of government decentralization achieved in Indian cities remains inadequate. Paralleling insurgent participation described by Miraftab and Wills [18] of the urban poor in South Africa, Harriss [27] suggests that the poor in urban India are left out of the new politics of participation, which spaces are occupied by middle class activists and associations who as 'consumer-citizens', speak the language of collaboration with local governments. For the poor, Harriss suggests, the principal possibility to obtain representation for themselves remains through political parties (ibid), which continue practices of patronage.

We suggest that the inadequacy of formal democratic institutions, procedures, space and capacity also results in the inadequacy of a deeper democratic politics in the city, for much of India. What then is the way forward for democratic deepening?

Miraftab and Wills suggest that planners, including planning professionals working outside government entities, need to work with the resources of the state as well as with the resources of citizens, and especially inclusive of those who are insurgent participants, who have invented their spaces of citizenship [18]. In this context, Heller's view [12] gives some hope to urban India, that with the strengths of social mobilization, and structured, local, procedural democratic engagement for participatory planning such as in Kerala and some parts of Brazil and South Africa, it is possible for democracy to be built bottom up. The following section describes such a structured, participatory democratic practice, that of Deliberative Democracy.

\section{Deliberative Democracy}

Modern deliberative democracy initiatives and discussions have emerged, largely in Western democracies over the last four decades. This article defines deliberative democracy as inclusive public deliberation that influences decision-making by an elected representative government. We view deliberative democracy as Heller and Rao (2015) posit, as an 'amalgam of deliberative process and institutionalized sanction' and 'that deliberation as such is not a substitute for electoral democracy but a necessary condition for deepening democracy' [51] (pp 7-8).

A range of deliberative democracy initiatives have been developed in recent years. These have dealt with complex urban issues of city-wide planning [52], to the allocation of $100 \%$ of the infrastructure budget in the capital city of Melbourne in an 'Australian Participatory Budgeting' initiative [53], and to national issues such as constitution formation processes in Turkey [54] and constitutional reviews in Ireland [55]. Concomitantly, deliberative democracy academic and practitioner discourse has examined the nature of public deliberation in society: how it may be embedded within a political system, particularly within electoral representative democracy, gains from public deliberation by everyday people, potential pitfalls, tools to organize deliberation, what essential qualities make deliberative processes valuable, and how the quality of deliberation might be evaluated, as well as the longer term impacts of deliberative democracy initiatives $[8,9,31,56]$.

According to Gastil and Richards '(W)hen people deliberate, they carefully examine a problem and arrive at a well-reasoned solution after a period of inclusive, respectful consideration of diverse points of view' [8]. While deliberation is essential in all types of democratic governments, representative, participatory and direct, Catt has suggested that deliberation within the community is the key characteristic of participatory democracy [57]. Fung (2012) proposed that the quality of democratic governance may be improved by considering three elements of institutional design: who participates in public deliberation; how they communicate and make decisions; and the connection between their conclusions and opinions on one hand and public policy and action on the other [58]. Further, as Mansbridge (2015) [59] suggested, democratic deliberation may be viewed as having epistemic, ethical, and political functions. The epistemic function relates to the generation of opinions, preferences, and decisions, informed by facts and logic. Participants in the deliberation consider, discuss and weigh a range of views and information. The ethical function refers to 
mutual respect and absence of coercion in the consideration of views or formation of decisions. The political function refers to inclusion and egalitarian nature of who participates in deliberation. This affects the quality and content of deliberation as well as its legitimacy. Carson \& Hartz-Karp (2005) [60] suggested three essential elements of an effective deliberative process as: 1 . Influence on policy and decision making; 2. Inclusion, of diverse viewpoints and values, providing equal opportunity for all to participate; and 3. Deliberation quality such that there is open dialogue, with access to information, space to understand and reframe issues, devise options, and search for common ground.

One of the cornerstones of deliberative democracy is participant inclusivity and representativeness. The method of 'sortition', or random selection, or selection by lot, has been proposed as ideal to ensure representativeness of the broad population involved, with stratified sampling to ensure the group selected mirrors the populations' demographics [61]. However, other methods may be used to ensure inclusion, depending on the nature of the deliberative forum, and such that the broadest spectrum of the population is elicited to participate [62].

The underlying contention of the practice and discourse of deliberative democracy is that if value is to be added to government decision-making, public participation needs to be meaningful i.e. have real potential to shape decisions or policies. In short, it should have influence'. This means that the decisions that emerge from a public deliberation are actually implemented, or integrated into the decisions and policies of the representative government. This ensures the deliberation has gravitas, which is important not only for those deliberating, but also for achieving implementable, sustainable, substantive outcomes [60,63].

Meaningful participation does not imply giving less importance to expert and technocratic views. Rather, it highlights that the values and considered views of the community involved are also important, and should influence decisions made. Not taking them seriously is highly likely to result in public resistance when government tries to implement changes. Officials responsible for urban governance and infrastructure are often criticised for making notoriously bad infrastructure decisions: being blind-sided by political dispositions, not seeing the big picture, inadequately examining options, and failing to understand project risks [64]. Moreover, their 'expert' solutions regularly backfire when there has been inadequate involvement of the diverse community. This is relevant in India too, as the media has often highlighted botched projects, that range from illconceived slum rehabilitation [65], flyovers [66], metro [67], and monorail [68], to a whole township [69].
We suggest that inclusivity, quality and influence of public participation in civic governance in Indian cities may be greatly enhanced through deliberative democracy, leading to more substantive outcomes for the public, and especially the marginalized. Moreover, given the importance of accountability and transparency to accrue public legitimacy for such deliberative democracy processes, we suggest it is important to have an overseeing, independent third party.

\section{An independent third-party}

According to Stephens \& Berner (2011) [70] "(T)he third party's role is to assist in designing and managing a process that pursues a variety of goals beneficial to the stakeholders and decision-maker(s)". In this instance, the goals are to achieve good governance. This is currently difficult to achieve given the noted prevalence of exclusionary organic participation, as well as the rising levels of public distrust in India's democratic governance [71], and the unsatisfactory experiences with most governmentinduced participation in Indian cities. We propose that this could be resolved if there was an independent third party, tasked with overseeing good governance.

The need for an independent third-party has been evidenced in the Indian experience of public participation, where independent facilitation has been required, often provided by non-governmental organizations (NGOs) and educational institutes. For example, participatory budgeting in Kerala and other cities around the world, as well as participatory planning in rural Maharashtra have documented the importance of an independent facilitation team in public participation processes [32, 33]. When the provision for conducting gram sabhas (village assemblies) was legislated, this did not inevitably lead to village assemblies automatically deliberating and preparing their development plans. Recognizing this gap, in 2018, the Indian Government launched a federal programme (the Rashtriya Gram Swaraj Abhiyan, national campaign for rural self-governance) to strengthen the capacities of rural local self-government institutions for participatory planning. The programme recognizes that developing Gram Panchayat Development Plans may require intensive facilitation, and envisages professionals and educational institutions providing such support to villages [40]. This is relevant in urban areas as well. Meaningful participation requires that participants receive unbiased, comprehensive information and reports written in ways that can be easily understood, regardless of participant levels of education. Additionally, public participation data needs to be collected and maintained. This is currently a significant gap in existing participation forums, which could be taken on by an independent third party.

In the deliberative democracy discourse, it has been proposed that a collaborative countervailing power is needed [31], to help foster the integrity of empowered 
participatory governance, and reduce its susceptibility to various forms of corruption. Sources of collaborative countervailing power, Fung \& Wright suggested [31], were NGOs or movements, with local groups potentially being best suited to this role. The recent formulation of the Forest Rights Act in India provided insights on the use of countervailing power via a different route - adversarial yet collaborative. Ganguly described the process as one that combined the utilization of formal deliberative spaces (in this case a Joint Parliamentary Committee) with mass mobilizations of tribal community groups and NGOs when those spaces were threatened, and then with NGOs playing mediation and facilitation roles [72]. Ganguly's description also highlighted how arguments and points of view were crystalized, not by the political sphere but by the independent deliberative public sphere. National advocacy organizations as well as local community groups were able to come together to form a broad national coalition that advocated for the rights of the historically marginalized. This combination served as a strong counter to the 'tiger versus people' argument of the conservationist NGOs that aligned with the Forest Department (ibid). While this outcome was highly effective, it is not always the case that such coalitions supporting the disadvantaged will emerge. Hence the inclusion of an independent third party as an integral part of the public participation process could help to provide that countervailing power, and enable/ upskill marginalized people to form empowered groups [10].

Hence while the Indian experiences of traditional organic and induced participation provide a foundation for good governance, the considerable gaps in effective public participation institution and practice highlight the need for governance reform in urban India. Considering the success of deliberative democracy in other parts of the world [56] and similarly structured and facilitated participation in rural India [32,33], there is reason to believe that Indian cities too could benefit from such reform. In particular, it is proposed that implementing deliberative democracy as an integral element of induced participation, and conjoining organic participation, would result in meaningful participation and bridge current gaps in good governance. If this conjoining was done synergistically, it would maximize the strengths of each, i.e., the commitment and energy of local organic participation with the authority and structure of induced participation. The claimed and invented spaces of participation would be important to broaden the base of those involved, bringing to the fore an understanding of the issues of those often excluded from government's purview, and providing the advocacy needed to press governments to enact the commitments made to their constituents. To achieve this, organic, claimed and invented participation would need to be formally integrated within each stage of the induced deliberative democracy process (i.e. accepted by all parties), from the initial framing of the problem and implementation of inclusive, deliberative processes, through to championing the implementation of recommendations, and ongoing review of impacts. Additionally, to ensure the participation process would be comprehensive, transparent, egalitarian and influential, it should be overseen by an independent third party, which would foster process legitimacy, and in so doing, bolster public trust in the democratic system.

The next section describes an action research initiative in Pune, India that explored how the traditional and ongoing strengths and energy of organic participation, together with structured, meaningful, induced participation opportunities could be utilised and enhanced to enable good governance in Indian cities.

\section{Methodology: pioneering new routes to achieve good governance - instituting deliberative democracy initiatives in Pune, India}

Pune, with a population of 3.5 million, is a prominent city in western India. As in many developing country cities, the expansion of the urban area, population increase and changes in lifestyles have exerted great pressure on municipal capacities. There is also considerable innovation and experimentation, often due to an active civil society [73].

Between 2013 and 2017, the authors were involved in a deliberative democracy action research initiative that was implemented to introduce high-quality public deliberations, successfully applied in developed cities, and assess their applicability to the Indian urban context. Inclusive, deliberative public participation was sought to improve neighbourhood street design and participatory budgeting. A mixed methods approach was used including interviews, public perception surveys, a collaborative inquiry with a team of facilitators and implementation of public deliberative processes, as performative components in an action learning cycle. The research goal was not only to advance theoretical understanding about deliberative democracy in the urban Indian context, but also to actually initiate such processes in Pune through a non-profit organization seeking to advance sustainability. This article limits the description of the action research to the public deliberation component. Bradbury-Huang [74] noted that in action research, understanding and action are not readily separable; and that 'only through action is legitimate understanding possible'. There is a dilemma in action research, that action researchers have a dual role as researcher and implementer or 'change agent' [75]. This was indeed the case in this action research on deliberative democracy initiatives in Pune.

The first initiative took place in 2013 in Dattawadi, to resolve chronic mobility and liveability problems. Though these concerns are key to relevant NGOs and 
a bus commuter forum, at that time, they had not engendered visible public or government concern. The second initiative described in this article took place in 2015 in Pune, to improve the city's Participatory Budgeting $(\mathrm{PB})$ process, which allocates scarce resources to urban projects. A number of $\mathrm{PB}$ initiatives have been carried out in Pune since 2007. Though they started out promisingly, the $\mathrm{PB}$ process has deteriorated over time. The reasons for selecting these topics for public deliberation were twofold. Firstly, in Pune, the use of streets as public space, mobility and road safety are ongoing concerns that cut across class and cultural segmentation, though the reasons for concern are varied. Secondly, improving the Participatory Budgeting process was chosen because it is a regular activity of the local municipal government, and though it is implemented ineffectively, it does still offer a structured annual forum for the public to be involved to a certain extent in decision-making.

In both deliberative democracy initiatives, challenges emerged from the outset including: the extent to which the government decision-makers were actually prepared to be involved; what roles supporting groups such as NGOs and tertiary institutions should play; how diverse public participation could be elicited including those usually excluded from such processes; and how the outcomes of such processes could influence change. As is likely in action research, the planned methodology needed to be adapted to the situations as they arose. As a consequence, the research resulted in learnings about the challenges of inclusive, deliberative models, and insights into how they might be addressed in the future.

The first challenge to the original plan arose as the initiatives progressed, when it became apparent that while government officials were prepared to go along with this work, it was more on the basis of look and see what happens', rather than active involvement. Hence, rather than overseeing and supporting the process, the NGOs and two tertiary institutions became the drivers and organisers of the processes. It also became apparent that to have public legitimacy, these participation processes would require the $\mathrm{NGO}$ and Universities to act as independent arbiters, so the broader public could have confidence that this work was worth their consideration and support. In short, the NGOs and Universities also took on the role of an independent third party. Obviously, this was not ideal. However, because the Universities and one of the NGOs in particular were perceived as having no special interests, it was plausible to the public for these organisations to jointly play the role of organisers and independent third party. Finally, there was the challenge of ensuring the deliberations resulted in some influence on decisions being made.
From this experience, it became clear that meaningful public participation in India would require a combination of a/ induced participation - the authority of government; b/ organic participation - the support of NGOs and community groups; and c/ an independent arbiter - an NGO or university or other trusted organisation to oversee the process. Moreover, for success, these three elements - induced participation, organic participation, and third-party oversight - would need to work effectively in tandem. From the experience of trying to conjoin these three elements, a framework was inductively developed. Mirroring this inductive pathway: 1 / the two deliberative democracy case studies in Pune, India have been described; $2 /$ the learning and insights from those case studies have been highlighted; and 3/ the potential role of an independent third party has been examined. The framework evolved from the experience of implementing these steps. This has been outlined in a table of roles and functions, and a figure charting the process.

\section{Results - deliberative democracy initiatives in Pune, India \\ Case study 1 : resolving street design and mobility challenges in Dattawadi, Pune, India}

Non-Government Organizations (NGOs) in Pune had been advocating for improvements in facilities for walking, cycling, public transport and mobility systems for several years. The advocacy included appeals to political leaders and municipal officials, seminars, and vision statements. Civil Society Organizations (CSOs) had also collaborated with the local government and offered technical inputs in developing projects, and capacity building workshops. This organic participation had resulted in some, but not much change on the ground. It was in this context that the Dattawadi process (fully described in Menon and Rapur 2018 [76]) was conducted in partnership with the Curtin University Sustainability Policy Institution (CUSP), the BN College of Architecture, and two NGOs, the Centre for Environment Education (CEE) and Parisar, together with the support of the local NGOs that had been urging the government to adopt urban mobility improvements. This initiative was one element of an AusAid action research grant, offered by the Australian government.

Dattawadi was selected to be the area of study after a deliberative process that involved a broad Pune stakeholder group, determined this to be the most appropriate area, based on the multi-purpose nature of street usage, multi-scalarity of the issues, and political support. The neighbourhood is about one square $\mathrm{km}$ in area, with a dense fabric of low-rise buildings. The area was largely inhabited after a local dam breach in 1961 when the flood-affected families were awarded land here. The neighbourhood is bounded by a very 
busy arterial and two collector roads. The inner streets have little traffic and see neighbourhood life and usage of the streets as a common open area. This typically includes street vending, shop front displays, recreation, mobility and residential activity such as water heating, water storage, children's play etc. Since this area was built before the motorization uptrend of the 1980s and 1990s (and which continues), the individual buildings do not have parking spaces. Almost all streets and footpaths have parked vehicles, mostly motor cycles. The increase in motorization and the busy traffic around the neighbourhood produces conflicts among different uses of the street, and the different modes of transport. The purpose of the deliberation in Dattawadi was to develop neighbourhood street design that would serve to enhance the quality of life of the residents and the broad range of street users.

As the first such process in Pune, the intent was also to demonstrate a high-quality deliberation process to diverse actors in Pune, including elected representatives, local government, experts, NGOs, academic institutions, media and members of the public. The process of preparing for the deliberative forums, conducting them, and submitting the documentation took place over a one-year period. It included discussion among the partners about the issue of street design, identification of the most appropriate neighbourhood to pioneer deliberative democracy, discussions with elected representatives to elicit their agreement on the conduct of such a process, local area studies about street usage, and discussions with different stakeholder groups in the neighbourhood to gather insights into the varying viewpoints on issues of concern.

Numerous techniques were employed to maximise the inclusiveness of the Dattawadi participants. Over one hundred people were involved in total, including official and unofficial workers and residents. Invitations were distributed through the elected representative to residents, and through meetings with the municipal community worker, local school, senior citizens, women's self-help group representative, shop keepers and street vendors. Arrangements were made for participant transport where needed, and payment of a compensation for daily wage workers. The public deliberation process took place over two days. A relatively large-scale deliberation was organized with 60 participants purposefully seated at small tables to maximise diversity, each table group being supported by a facilitator from the host organisations as well as partner NGOs. The facilitators received training prior to the event to understand the processes and techniques to be used for the deliberation. Throughout, presentations and conversations were translated into two languages, English and Marathi (the local language). The 21st Century Deliberation ${ }^{3}$ technique, ideal for medium to large scale deliberations, was used with an online platform (Civic Evolution) ${ }^{4}$ to network the participants' small group table discussions. All participants' ideas were submitted to their table's computer; these were themed by an independent group, and later displayed on large screens, enabling individual participants to prioritise their preferred suggestions. A Workshop Outcomes Report [77] of the day's process and findings was disseminated to all participants at the close of the day. A second public deliberation process was held the next afternoon without the online technology, with about 80 participants, including those from the first day deliberation as well as other interested community members. Their task was to assess the street options developed by the BN College students, who overnight and the following morning had designed options that reflected the priorities of the first deliberation.

The two days of deliberation recommended the features participants wanted to keep in Dattawadi and those they wanted to change, and prioritised those plans deemed most beneficial to the area. The local councillor and a Member of Parliament who attended the first day's deliberations, saw the value of the process and publicly agreed to fund the implementation of the agreed deliberation priorities. However, actual implementation was limited. In part, this was due to the lack of follow-up processes to ensure the government carried out its commitments; but also, it was due to the municipality baulking at some street design recommendations which deviated from the municipality's standard designs and materials. This outcome was very disappointing, especially since the municipal decision-makers had announced at the public deliberations, and recorded in the local newspaper, that they would support all the deliberation recommendations. It was precisely because of government's publicised intentions to implement the recommendations that the NGOs involved did not follow their usual course of action to maintain pressure on the government, both elected officials and relevant government agencies, to carry through with their commitments. Although the immediate implementation of changes was limited, the process was influential in the longer term. When the deliberations began in Dattawadi in 2013, the city had just begun to develop street design guidelines. Even though this deliberative democracy process alone did not significantly impact the trajectory of change towards improved street design at the city scale, the Dattawadi experience did provide momentum with some clear directions forward. Additionally, it demonstrated the usefulness of organic participation working in tandem with induced public deliberation, overseen by an independent third party. Furthermore, a few years later, the learnings from this initiative assisted in the development of the PB deliberative review initiative. 
Case study 2: review of participatory budgeting in Pune Since the initiation of Pune's Participatory Budget process in 2006-7, annually, citizens are invited to submit suggestions for neighbourhood projects. Each electoral ward has an equal and fixed budget allocation for PB projects. From August to September, participants have a window of 4 to 6 weeks to submit suggestions using a printed form or online. Once received, ward-level municipal officials assess the feasibility of suggestions, including their approximate value (which is capped). Finally, the elected Prabhag Samitis (ward councils) make decisions about whether these suggestions will be incorporated into the city budget.

In 2013, CEE carried out a review [39] of Pune's PB, which revealed that when the $\mathrm{PB}$ was introduced in 2007, it had shown promise as a potential deliberative forum. In the first year, ward-wise group meetings were held where participants discussed each of the suggestions received and prioritized these. However, this practice was only partially continued in subsequent years. Though the annual process for submitting suggestions had continued to be simple and accessible to all, only a few hundred suggestions had been received every year. The $\mathrm{PB}$ process had not been transparent, neither regarding which projects were included in the budget nor whether they were implemented. Although a potentially powerful initiative, according to the indicators of a successful PB, Pune's PB had been deficient [39]. An additional review was carried out using inclusive deliberative participation to make suggestions for Pune's $\mathrm{PB}$ in 2014. This process suggested the addition of several steps to the PB process, including participatory social audits of the previous year's projects, information on the projects already budgeted for the year, and preparation of status reports on civic services in each ward. While this review process resulted in useful, implementable recommendations, government did not implement them.

In 2015, CEE, Parisar and Curtin University organized a second inclusive deliberative forum with a view to refining the protocols for Pune's PB along with the municipal government, and supported by the Municipal Commissioner. This was at the initiative of CEE, which had been involved with $\mathrm{PB}$ over the years, and could see the annual PB as being a potential vehicle to introduce area-based participatory governance and deliberative democracy processes. Participants were recruited from the broad public to elicit diversity in terms of age, gender and economic background, ensuring representation of those normally excluded from such processes. They included street vendors, women's organisations, college students, neighbourhood association representatives, differently-abled persons, and professionals. Though randomly selected participants from varied streets were elicited, and public survey respondents who had expressed interest in attending were also invited, few participated. Approximately 50 participants attended. Some municipal officials were present throughout the deliberation, including a Zonal Commissioner and the Environment Officer. While invitations had been sent to several officials, the ones who attended probably did so out of general interest, since they were themselves involved in some form of public engagement. The process began with presentations of the Pune PB review, and global PB best practice. Applying the 21st Century Deliberation technique, participants in small deliberation groups submitted to their table computer ways to increase participant diversity and ways to 'share power' in the prioritization of projects and their implementation. Participant ideas were first individually prioritized, then combined to form a list of the room's preferences in order of importance for strengthening Pune's PB process.

The deliberation output was a Workshop Outcomes Report [78], prepared in Marathi and English, which was presented to attending municipal and elected representatives, distributed to all participants, and later, submitted to the local government. The Municipal Commissioner committed to immediately discussing the workshop outcomes with the municipal administration. One promising outcome was that the PMC then entered into a partnership with CEE to prepare a Ward Infrastructure, Services and Environment (WISE) information base and Index, and also placed the budget online in a form permitting easier analysis. This enabled more empowered public participation [79]. Using a range of indicators, WISE provided the public a reference point for the status of civic amenities and services and rationale for budget allocations. The scores for each ward were used to calculate and yield a relative development index. However, in the subsequent budgeting process, the elected officials did not fully accept the WISE rationale [80], and their reasoning behind fund allocations remained opaque to the public.

This again highlighted the tenuousness of meaningful participation in the Indian context. Good governance demonstration projects, and organic participation advocacy play an important role in fostering change. However, for good governance to be institutionalized, i.e. become 'business as usual', this could well require formal reform in urban governance.

\section{Discussion}

In this section we discuss the results of the two Pune deliberative forum case studies, firstly in terms of the key features of deliberative democracy, and secondly assessing how the integration with organic and induced participation processes worked, and the role of the third 
party. These findings are based on the reflections of the organisers and facilitators from both deliberative democracy initiatives, as well as the formal feedback from the deliberation participants.

\section{How deliberative democracy was incorporated into induced participation}

Considering the deliberative forums as a form of induced participation, we discuss here the extent to which they achieved the three key principles of deliberative democracy - inclusivity, deliberativeness and influence.

\section{Achieving inclusiveness/ representativeness}

Our attempts to recruit participants in Pune through random selection revealed significant challenges and the need for creative thinking to get diverse voices in the room. Endeavouring to randomize from the Pune electoral roll revealed large-scale errors in the rolls. This finding was consistent with other more rigorous studies on electoral rolls in India [81]. Another randomized effort involved inviting participation from a pool of individuals from randomly sampled survey respondents who had been willing to share their contact information for future discussions. This however, did not produce useful results as those contacted could not make the time.

Additional efforts included random face-to-face elicitation. However, this too resulted in challenges: several women approached were very unwilling to participate and asked for the men in the family to substitute (e.g. a woman saying, 'I am not a citizen, please talk to my husband'); and, given the lack of precedent for officials to invite everyday people in the street to participate in a public event, these requests were often treated with suspicion or fear. Further, people in informal occupations could not afford to participate without compensation for the earnings they would forfeit on the days spent in the deliberative meetings. Moreover, prolonged absence from the place of occupation or service provision could result in their displacement, and loss of several days' earnings.

The goal of eliciting diverse perspectives in the room was more usefully achieved by ensuring that representatives of the variety of people in the neighbourhood and different types of users of the street were in the room, rather than through rigorous random sampling. Diverse participation in both Pune public deliberations was achieved though face-to-face encounters on the streets and requests to a broad range of CSOs for representatives from different types of street users and different age groups of people on the street, those using different modes of transport, street vendors, and people from different residential areas including the slum community.
While stratified random sampling is considered highly desirable for recruiting participants, other methods are useful as well, and may be more suited depending on the purpose of the deliberative forum. A random sample may also still leave out minority groups, especially if the sample is small. Purposive sampling and recruitment may be done to include specific group members, such as those most impacted, or most marginalized, and may also consider over-inclusion of certain groups [62, 82]. The goal is to have equitable representation and a diversity of attitudes and viewpoints within the deliberating group.

\section{Achieving deliberativeness}

Gastil has suggested that the key practices of deliberation are to create a solid information base, prioritize the key values at stake, identify a broad range of solutions, weigh the pros, cons, and trade-offs among solutions and then make the best decision possible [83].

The facilitators' tasks to enable deliberativeness include framing the issues being discussed to be inclusive, setting ground rules for the discussion, encouraging equity and respect, and helping groups analyse issues and make decisions [84] . Good facilitation may be considered an art [85] as things may not go according to plan. A facilitator may design a deliberation plan and then have to adjust it depending on the needs of the situation. The skills of facilitators, their social intelligence, and their understanding of what is important for the deliberation are key to effective deliberation. The facilitation role calls for remaining independent, and balancing the group process, the task at hand, and the individuals involved. Facilitators need to create an environment that nurtures the social aspects of deliberation, including the adequate distribution of speaking opportunities, mutual comprehension, consideration of others' ideas and experiences, and respect for other participants [83].

In both case studies, the qualities of good deliberation were largely achieved, though sometimes with difficulty. Overall, however, the feedback indicated that good facilitation enabled respectful listening as well as the elicitation of participant values, discussion of diverse options, and prioritization of ways forward.

In the Dattawadi deliberations, the University worked to provide unbiased and comprehensive information, though particularly architectural maps and graphics were not easily understood by all participants. Ensuring easily understood information could be an additional role overseen by the independent third party.

In both case studies, broad and open framing of the deliberation question ensured all viewpoints could be safely aired. Researchers [86] have suggested that both in normative and operational terms, independent analysts are useful to encourage participants to consider different 
ways of thinking about the issue under discussion, not only counter-arguments, but counter-frames. From our experience, the independent third party could also take on this role, especially if they have already ascertained this information during the background research that should have included a broad range of experts, advocates of organically arising issues, and those likely to be impacted by decisions made.

The different languages spoken by participants did not seem to impede deliberation, with facilitators providing translations. Fung and Wright noted (6) that the high literacy rate in Kerala was an enabling factor for participatory planning and budgeting. However, from our experience, if efforts were made to enable two-way communication in non-textual modes, participant literacy was not essential. In Dattawadi, the information collected in the prior studies as well as the street design prepared were presented orally and with photographs and illustrations. Where text was used, such as in the prioritization exercises, the options were read out by the facilitators in each group and discussed. The conduct of the deliberations in small facilitated groups helped provide each person adequate opportunity to speak. Once again, we suggest that an independent third party could oversee efforts to ensure disadvantaged, illiterate or semi-literate groups could meaningfully participate in deliberations, potentially bolstering their sense of selfefficacy and group empowerment.

Balancing the power differential in India's stratified society was the most difficult group dynamic to manage. In one particular example, an egalitarian environment was not successfully maintained when street vendors were seated with local representatives on the same table, and it became apparent that the street vendors always agreed with the local representative. Existing power dynamics appeared to stifle open and free dialogue. Such power-over relationships could be mitigated with stronger facilitation and/or with purposeful seating to avoid such power-over relationships at the one table. Then the views of the vulnerable could be voiced in the deliberations without worries about repercussions. Additionally, preparatory workshops of more vulnerable groups could be held prior to the deliberation to strengthen their skills and confidence. Again, the independent third party could take on the task of finding ways to include impacted, marginalized groups, avoiding negative fall-outs, if they were not able to form an effective 'counter-public'.

The Dattawadi process was not formally evaluated through quantitative surveys, though qualitative participant feedback was sought orally at the end of the day. The PB review process, on the other hand, was assessed through a quantitative feedback questionnaire administered at the end of the process, with facilitators working with non-literate participants to record their feedback. The questions pertained to assessment of the key characteristics of public deliberations, including the usefulness of the information provided, the deliberative quality including respectfulness, and the satisfaction with the outcome. Participants rated the forum highly on all of the above aspects.

\section{Achieving some, but very limited influence}

Deliberative democracy highlights the need for influential public deliberation. Ideally the recommendations of a mini-public are accepted and implemented. The implementing agency would usually be a government agency, but recommendations may also be for the community itself to implement, or other entities. Though the Dattawadi case held the promise of such influence, implementation only minimally materialised in accordance with the designs envisaged. The PB review was influential insofar as the local government did go forward with the development of an information base and public infrastructure index to support rational budgeting. ${ }^{5}$ However, in the following year, though the Municipal Commissioner did introduce this rationale in budget making, the budget decisions made by elected representatives did not reflect the usage of this information [80].

In the absence of formal governance reform, keeping government honest is no easy task. Additionally, in India, as public participation is rarely legislated, efforts made in this regard are entirely voluntary. Although the lack of impact of such initiatives has not been clearly documented, as this research documents, even when clear government commitments had been made to influential public deliberation, the outcomes of these initiatives did not translate into action on the ground. The reasons were no doubt typical of government reluctance to adopt new practices. For example: government representatives apparently wanted public acceptance, but not enough to expend the limited budget on the public's recommendations; there was a lack of timeliness in the government response, so the issues raised faded from urgent to chronic; there was departmental unwillingness or inability to implement initiatives that were out of the ordinary; and over time, the history and context of the initiative were lost with changes in elected representatives and/or administration officials.

Suggested mechanisms to foster the influence of future public deliberations include:

- Continuing advocacy of civic groups throughout and following the deliberative process.

- Ongoing implementation of inclusive, deliberative, influential demonstration projects involving the broader public throughout. 
- Iterative deliberations, one building on the next, gaining momentum as broader issues and more people are involved.

- Promoting institutionalization of more meaningful public participation in governance as in Kerala, Maharashtra and Mendha Lekha, as well as innovative methods such as the Citizens' Initiative Review (CIR) in Oregon, USA.

It should be noted that research elsewhere has shown positive long-term effects of deliberative democracy initiatives on citizen efficacy [87]. This has also been evidenced in Kerala's Kudumbashree programme, which has resulted in greater public participation by urban poor women in ward meetings after participating in microplanning in their own neighbourhoods [41]. Indeed, participant feedback from both Pune deliberative democracy case studies indicated that participating appeared to enhance their sense of self-efficacy, civic understanding and potential civic participation in the future - all important to effective democratic governance.

\section{How organic participation added value to deliberative democracy induced participation}

It is our contention that deliberative democracy in Indian cities needs to build upon the wealth of participatory initiatives, advocacy efforts, and the spaces claimed or invented through movements and struggles. In Dattawadi, the learning from involving organic participation included:

- Organic participation was crucial to gaining the trust and inclusion of the marginalised and disempowered.

- With known and trusted civic groups standing alongside elected representatives, the participatory process was able to accrue greater legitimacy.

- The deliberation issue became more broadly owned by both the public and the elected representatives

- Members of organic groups, used to dealing with a diversity of views, helped the deliberation process, in particular as facilitators, translators and scribes.

- Funding of the project and implementation of some of its recommended designs were made possible through the conjunction of well-known civic groups, governmental officials and publicly trusted organisations, including universities.

In the $\mathrm{PB}$ review, there were similar learnings to those from Dattawadi, plus the following:

- Organic participation (CEE and others) had continually tried to improve the inclusivity and influence of the Pune PB process through studies and critiques $[39,88]$, but with little success. This new method of including diverse voices in considered deliberation had some success in that the government did commit to seriously considering its recommendations.

- The deliberative democracy PB Review also succeeded in gaining government recognition that change was needed to their PB process. This has given civic groups hope that through their continued advocacy, the deliberative review recommendations, including the usage of the WISE InfoBase and index, will be implemented.

\section{How the role of an independent third party functioned}

For meaningful participation to elicit public legitimacy, the process and the parties involved need to be seen to be trustworthy - inclusive and egalitarian, transparent and accountable. This can best be achieved by an independent third party. In the Pune case studies, in the absence of government interest in democratic renewal, the consortium of academic institutes and NGOs took on the role of piloting high-quality public deliberation to demonstrate good governance. As well as driving and administering the initiatives, they played the role of an independent third party, conducting background studies, framing, arranging and facilitating the deliberations, while overseeing each project to ensure its processes were open, inclusive, egalitarian, accountable and transparent. The fact that the consortia had taken on this role was neither initially recognized nor specifically evaluated. However, the participant feedback on each of the different elements of a trustworthy process were highly evaluated - regardless of who was responsible.

Based on our action research, and the literature on how public deliberation forums are conducted elsewhere, we suggest that the roles of a Third Party could include predeliberation preparations such as background research, preparatory meetings, especially with marginalized groups, framing the deliberation, preparing the input materials in easy to understand formats, and designing the deliberation process. The tasks during and immediately after the deliberative forum could include facilitating the deliberation, soliciting participants' feedback, preparing an evaluation of the deliberations and the report of the deliberation. Third Parties could also contribute to broader reviews of deliberation processes and provide suggestions to the organizing entities, typically the government.

Based on our action research learnings, we have attempted to inductively derive a process flow of a deliberation process that could be anchored by the government, facilitated by a third party and could integrate organic advocacy agencies. Our suggestion is that public deliberation 
processes could be organized periodically (such as annual Participatory Budgets), as well as around particular issues or projects, and especially in response to the needs of the marginalized since such issues have often remained unresolved. The careful attention and deep thinking from multiple points of view that an issue would get in an inclusive public deliberation could help build real solutions, political will, and positive ways forward. The roles in such a process are outlined in Table 1, while the generic flow of such a process is pictured in Fig. 1. It should be noted that this Table and Figure which have evolved from our particular experience are presented as potential guides for others beginning this journey. However, contextual issues need to be at the forefront of any future endeavours. There is unlikely to be any one particular way of designing a public deliberation - so adaptations will be almost inevitable.

\section{Conclusions}

Improving urban governance is an imperative for India, with its accelerated rate of urbanization. The stratified and complex socio-economic and political context in India, power imbalances, and inadequacy of information for civic decision-making makes public engagement challenging. It is an opportune moment in India for deliberative democracy innovations. The rising interest in participation, together with discontent with current participation methods and governance can provide fertile ground for deliberative democracy to take root.

Using the learnings from action research case studies in Pune, we have shown in this article that a combination of leaders willing to pioneer good governance, capable third-party facilitators, and strong organic participation groups working together through the structured approaches of deliberative democracy can effectively integrate the public into civic decision-making. The add-on value of organic participation is particularly relevant in the Indian context for several reasons including its ability to highlight important issues of

Table 1 Conjoined Induced and Organic Participation aided by an Independent Third Party

\begin{tabular}{|c|c|c|c|}
\hline$\overline{\text { Role }}$ & $\begin{array}{l}\text { Induced Participation } \\
\text { by Government }\end{array}$ & $\begin{array}{l}\text { Third Party commissioned by } \\
\text { Public Deliberation Office }\end{array}$ & $\begin{array}{l}\text { Organic Participation } \\
\text { Advisory support by NGOs }\end{array}$ \\
\hline Suggest topics for deliberation (by the public) & & & $\circ$ \\
\hline Receive topics for deliberation & $\bullet$ & & \\
\hline $\begin{array}{l}\text { Prioritize topics through a panel (random selected public } \\
\text { and elected officials + experts, civic officials) }\end{array}$ & $\bullet$ & & \\
\hline Research the topic, map stakeholders & $\circ$ & $\bullet$ & $\circ$ \\
\hline Hold preparatory meetings with different stakeholders & $\circ$ & $\bullet$ & $\circ$ \\
\hline Frame the deliberation & $\circ$ & $\bullet$ & $\circ$ \\
\hline Compile and prepare materials for the public to review & $\circ$ & $\bullet$ & $\circ$ \\
\hline Design deliberation process and its evaluation method & $\circ$ & $\bullet$ & $\circ$ \\
\hline Appoint an oversight committee & $\bullet$ & & \\
\hline Recruit an inclusive, representative group of deliberators & $\bullet$ & $\circ$ & $\circ$ \\
\hline $\begin{array}{l}\text { Provide participation support, if needed (wage } \\
\text { compensation, travel, child care) }\end{array}$ & $\bullet$ & & \\
\hline Conduct and facilitate the deliberation & $\circ$ & $\bullet$ & $\circ$ \\
\hline Prepare the evaluation of the deliberation & & $\bullet$ & \\
\hline Prepare the report of deliberation (including evaluation) & & $\bullet$ & \\
\hline Publish the report of the deliberation & $\bullet$ & & \\
\hline Submit the report to the relevant government authority & $\bullet$ & & \\
\hline $\begin{array}{l}\text { Publish how deliberation recommendations are } \\
\text { incorporated in government decisions }\end{array}$ & $\bullet$ & & \\
\hline Track and follow-up to ensure implementation & & & $\circ$ \\
\hline Review of the process, implementation and impacts & $\circ$ & $\bullet$ & $\circ$ \\
\hline $\begin{array}{l}\text { Report learning with suggested changes or adaptations for } \\
\text { the future }\end{array}$ & $\circ$ & $\bullet$ & \\
\hline
\end{tabular}




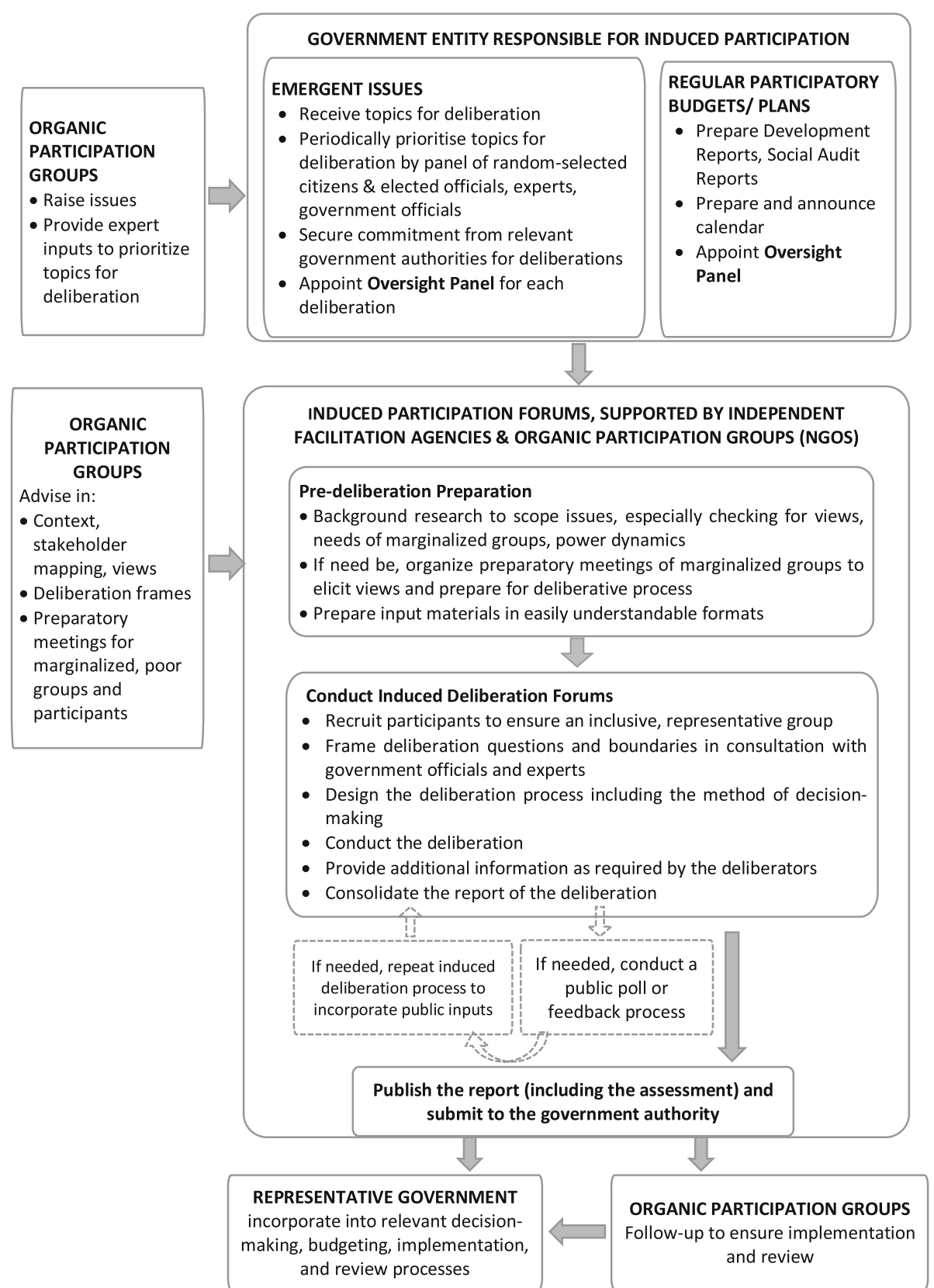

Fig. 1 Process flow chart on key steps for high quality public deliberation with organic and induced participation characteristics, facilitated by an independent third party

concern for public deliberation, as well as the expertise, deep involvement and perseverance of advocacy groups. In particular, deliberative democracy can purposefully include those publics that are often not invited into the formal consultation-oriented participation spaces of government induced processes. Deliberation processes can and should aim to address such exclusions, that are also the reason India is called an 'unlikely' democracy.
To promote and facilitate public deliberations, the role of the independent third-party can be played by universities or NGOs that enjoy public trust, as has been the experience in Kerala, and rural Maharashtra. Additionally, the process flow we have inductively derived for conjoined organic and induced deliberative democratic participation, facilitated by an independent third party can be a useful reference point for future efforts. 
However, achieving ongoing good governance in India will be a challenge. It will require an organic movement not just to call for, but also help implement governance reform in Indian cities. It will require advocacy at multiple levels to encourage and support governments to implement deliberative democracy processes, strengthen the skills and willingness of organic participation, and advance an effective independent third-party to promote, oversee and ensure best practice public participation in governance. Such advocacy will need 'champions' within political, administrative and civil society willing to try out public deliberations. A key challenge will be to overcome scepticism among leaders. Leaders of issue-focused organic advocacy who may well perceive risks in 'going to the general public', that is beyond their particular interest groups and political or administrative decision-making venues, and in particular, potentially giving the floor to those with opposing views, thus hampering their organization's advocacy. Moving past such critiques will require involving those likely to resist or oppose in different roles in meaningful public deliberation initiatives. For example, they could be involved as members of overseeing groups, or as community 'experts' who present their views to deliberation participants and are questioned by them.

Additionally, it will require ongoing research and evaluation of good governance initiatives that can enable continual adaptation and foster ongoing innovation. Working in cooperation, an ecosystem for democratic renewal can be created. This will be integral to the ability of Indian cities to more effectively resolve their highly challenging urban sustainability dilemmas.

As has been evidenced elsewhere, nothing succeeds like success, that is, such efforts can create a virtuous cycle and repetition of such processes is more likely if they were seen to be successful. This was also the experience in Pune, with collaborators and key civil society actors who were part of the organizing teams later becoming advocates of deliberative democracy. Experience elsewhere has demonstrated that well designed, well implemented, inclusive, influential public deliberations have proven to be highly successful in accruing public legitimacy $[53,89]$.

Some starting points to introduce deliberative democracy initiatives in Pune and other Indian cities include: the application of recent national guidelines for urban master planning, ${ }^{6}$ conducting pilots to operationalize the area sabha provision in municipal law in states that have created such a provision, and adding deliberative democracy processes in initiatives by municipal line departments, such as for improving waste management, street designs, access to welfare benefits, introducing or strengthening participatory budget processes. Deliberative democracy can provide the opportunity for deepening democracy, addressing some of the core conditions that make India an 'unlikely democracy', and enabling democratic structure and democratic politics to come together at the granular level of governance that cities provide.

\section{Endnotes}

${ }^{1}$ Mohan Hirabhai Hiralal, pers. comm., September 2016 https://puneabhyasgat.wordpress.com/2016/11/29/ notes-2-sept-2016/

${ }^{2}$ Mohan Hirabhai Hiralal, an activist researcher, has supported the evolution of remarkable deliberative democracy processes over several years in Mendha Lekha, a tribal village in eastern Maharashtra. Abhyas gats or study circles, are convened of interested individuals from the village community on issues of public or community interest. These study circles act as a deliberative space for considering issues of interest, and include deliberation on inputs of invited experts, views from the village community, working through information, expert inputs, diverse views and arriving at potential ways ahead. The deliberative space, that is the study circles, are different from the decision-making space, that is the gram sabha, which is the assembly of all adults of the village. The results of deliberation are presented to the gram sabha where decisions are made through consensus, with quorum. If consensus is not achieved, the issues are referred back to the study circles for further deliberation., Maharashtra. See also https://kalpavriksh.org/wp-content/uploads/ 2019/01/Community-Conserved-Areas-in-India.pdf

${ }^{3}$ The 21st Century Deliberation involves a large number of people, organized into small, facilitated discussion groups using networked computers. Each table's suggestions to designed open questions are collated and then prioritised by participants, with a Participant Report disseminated at the conclusion.

${ }^{4}$ CivicEvolution was an online software tool that enables rapid collation of content from different groups of discussants using networked computers, and subsequent prioritization if needed. A newer version is now available as WhatDoWeThink at https://whatdowethink.com/

${ }^{5}$ See http://ourpuneourbudget.in/

${ }^{6}$ The Urban and Regional Development Plans Formulation and Implementation Guidelines 2015 (URDPFI), issued by the Government of India recommend participatory planning and citizen engagement.

\footnotetext{
Abbreviations

CAA: Constitutional Amendment Act; CEE: Centre for Environment Education: CIR: Citizens' Initiative Review; CSO: Civil Society Organization; CUSP: Curtin University Sustainability Policy Institute; NGO: Non-governmental

Organization; PB: Participatory Budget; WISE: Ward Infrastructure, Services and Environment (index or information base)

\section{Acknowledgements}

The authors acknowledge the support provided by Curtin University Sustainability Policy Institute, Centre for Environment Education, Parisar, BN College of Architecture and the Pune Municipal Corporation in the conduct of the public deliberations. We especially acknowledge the contributions of colleagues at CUSP and CEE, and the suggestions of the anonymous
} 
reviewers that helped improve the clarity, structure and content of this article.

\section{Authors' contributions}

SM and JHK are responsible for the conception and design of this article, drafting the manuscript, and for final approval of the version to be published. SM is accountable for all aspects of the work and ensuring the accuracy or integrity of the work. All authors read and approved the final manuscript.

\section{Authors' information}

SM is Senior Programme Director at Centre for Environment Education, a non-profit with a mandate to enhance public understanding of environment and sustainability. She is based in Pune, India. Her work includes schoolbased environmental education, and education for sustainable development in the urban context. She has led public engagement processes for introduction of bus rapid transit and formulation of a citywide bicycle plan in Pune, India.

JHK is a professor at Curtin University Sustainability Policy (CUSP) Institute, Western Australia. She is a well-known practitioner, teacher and researcher in deliberative democracy and sustainability. Janette has worked with Australian state and local governments, also governments, NGOs and universities in Canada, Israel and India, designing and implementing deliberative democracy action research. Innovative initiatives included Australia's 1st Citizens' Parliament, and 2 Citizens' Panels, one allocating 100\% of a City-region's operational budget, and the other allocating 100\% of the 10-year infrastructure budget; with the elected Council implementing all their key recommendations

\section{Funding}

This research was funded by AusAID Public Sector Linkages Program Project 65080, Australia-India Council grant number June14105 and the Centre for Environment Education.

\section{Availability of data and materials} Not applicable.

\section{Ethics approval and consent to participate}

Ethics approval was obtained.

\section{Consent for publication}

Not applicable.

\section{Competing interests}

The authors declare they have no competing interests.

\section{Publisher's Note}

Springer Nature remains neutral with regard to jurisdictional claims in published maps and institutional affiliations.

Received: 9 November 2018 Accepted: 23 May 2019

Published online: 16 July 2019

\section{References}

1. Primary census abstract data. Government of India; 2011. (Census of India).

2. World Urbanization Prospects 2018. UN Population Division; 2018 [cited 2018 Oct 14]. Available from: https://population.un.org/wup/CountryProfiles/.

3. Carcasson M. Tackling wicked problems through deliberative engagement Colorado municipalities; 2013. p. 9-13.

4. Fung A. Varieties of Participation in complex governance. Public Adm Rev. 2006;66:66-75

5. Sen AK. Democracy as a universal value. J Democr. 1999 Jul 1;10(3):3-17

6. Van Reybrouck, David. Against elections: the case for democracy. Kindle Edition; 2017.

7. Dalton R. Is citizen participation actually good for democracy? Democratic Audit; 2017. [cited 2018 Oct 10]. Available from: http://www. democraticaudit.com/2017/08/22/is-citizen-participation-actually-good-fordemocracy/.

8. Gastil J, Richards R. Making direct democracy deliberative through random assemblies. Polit Soc. 2013;41(2):253-81.
9. Dryzek JS, Hendriks CM. Fostering deliberation in the forum and beyond. In: Fischer F, Gottweis H, editors. The argumentative turn revisited: public policy as communicative practice. Durham: Duke University Press; 2012. p. $31-57$.

10. Fraser N. Rethinking the public sphere: a contribution to the critique of actually existing democracy. Social Text. 1990;(25/26):56-80. https://doi.org/ $10.2307 / 466240$

11. Waheduzzaman W, As-Saber S. Community participation and local governance in Bangladesh. Aust J Polit Sci. 2015;50(1):128-47.

12. Heller P. Degrees of democracy: some comparative lessons from India. World Polit. 2000;52(4):484-519.

13. Ganguly S. India's Unlikely Democracy: Six decades of Independence. J Democr. 2007:18(2):30-40.

14. Varshney A. India Defies the Odds: Why democracy survives. J Democr. 1998;9(3):36-50

15. Rudolph SH, Rudolph LI. South Asia faces the future: new dimensions of Indian democracy. J Democr. 2002;13(1):52-66.

16. Ambedkar BR. Annihilation of caste. 2013th ed. New Delhi: Samyak Prakashan; 1936

17. Mansuri G, Rao V. Can participation be induced? Some evidence from developing countries. Crit Rev Int Soc Pol Phil. 2013;16(2):284-304.

18. Miraftab F, Wills S. Insurgency and spaces of active citizenship: the story of Western cape anti-eviction campaign in South Africa. J Plan Educ Res. 2005; 25(2):200-17.

19. Cornwall A. Locating citizen Participation. IDS bulletin. 2002 [cited 2019 Apr 14];33(2). Available from: https://bulletin.ids.ac.uk/idsbo/article/view/1206.

20. Roy A, Dey N, Kashyap P. Allowing people to shape our democratic future. In: Kothari A, Joy KJ, editors. Alternative futures: India unshackled. AuthorsUpFront; 2017. p. 120-37.

21. Goswami D, Tandon R. Civil Society in Changing India: emerging roles, relationships and strategies. Dev Pract. 2013;23(5-6):653-64.

22. Chikarmane P. Integrating waste pickers into municipal solid waste Management in Pune, India: WIEGO; 2012. (WIEGO Policy Brief (Urban Policies)). Report No.: 8. Available from: http://wiego.org/sites/wiego.org/ files/publications/files/Chikarmane_WIEGO_PB8.pdf

23. Appadurai A. Deep democracy: urban governmentality and the horizon of politics. Environ Urban. 2001;13(2):23-43.

24. Putnam R, Leonardi R, Nonetti RY. Making democracy work: civic traditions in modern Italy. Princeton: Princeton University Press; 1993.

25. Sorensen A, Sagaris L. From Participation to the right to the City: democratic place Management at the Neighbourhood Scale in comparative perspective. Plan Pract Res. 2010;25(3):297-316.

26. Sen A. The argumentative Indian: writings on Indian history, Culture and Identity London: Penguin Books; 2005.

27. Harriss J. Antinomies of empowerment: observations on civil society, politics and urban governance in India. Econ Polit Wkly. 2007;30(6):2716-24.

28. Chatterji T, Soni A. Positioning urban governance in planning pedagogy. In: Kumar A, Meshram D, Gowda K, editors. Urban and regional planning education. Singapore: Springer; 2016. p. 61-77.

29. Singh B. Parallel structures of Decentralisation in the mega City context of urban India: Participation or exclusion? Space Polity. 2012;16(1):111-27.

30. Kumar S. Clean Air, Dirty Logic? Environmental Activism, Citizenship, and the Public Sphere in Delhi. In: Desai R, Sanyal R, editors. Urbanizing Citizenship: Contested Spaces in Indian Cities: SAGE India; 2011.

31. Fung $A$, Wright EO. Deepening democracy: institutional innovations in empowered participatory governance. London: Verso; 2003.

32. Heller P, Harilal KN, Chaudhuri S. Building local democracy: evaluating the impact of decentralization in Kerala, India. World Dev. 2007;35(4): 626-48.

33. Yashada. Integrated Gram Panchayat Microplanning: an effective tool for decentralized planning processes in Backward Region Grant Fund (BRGF) programme - Lessons from BRGF action research pilot project in Maharashtra (2010). Yashada;

34. Mahadevia D, Joshi R, Sharma R. Integrating the urban poor in planning and governance systems, India. Ahmedabad: Centre for Urban Equity, CEPT University; 2009. [cited 2018 Sep 18]. Available from: https://cept.ac.in/ UserFiles/File/CUE/Working\%20Papers/Revised\%20New/03CUEWP3_ Integrating\%20the\%20Urban\%20Poor\%20in\%20Planning\%20and\% 20Governance\%20Systems\%2C\%20India.pdf

35. Kuruvilla Y, Waingankar S. Ward committees, citizen Participation and urban governance: experiences of Kerala and Maharashtra; 2013. 
36. Cabannes Y, Lipietz B. Revisiting the democratic promise of participatory budgeting in light of competing political, good governance and technocratic logics. Environ Urban. 2017;30(1):67-84.

37. Sintomer $Y$, Herzberg C, Röcke A, Allegretti G. Transnational models of citizen Participation: the case of participatory budgeting. Journal Public Deliberation. 2012;8(2):9.

38. Wagle S, Shah P. Case study 2 - Porto Alegre, Brazil: participatory approaches in budgeting and public expenditure management. World Bank; 2003.

39. Menon S, Madhale A, Karan A. Participatory budgeting in Pune: a critical review. Centre for Environment Education; 2013.

40. Framework for implementation of Rashtriya gram Swaraj Abhiyan [Internet]. Government of India Ministry of Panchayati Raj; [cited 2018 Oct 28] Available from: http://rgsa.nic.in/resources/files/FrameworkRGSA. pdf.

41. Williams G, Thampi BV, Narayana D, Nandigama S, Bhattacharyya D. Performing participatory citizenship - politics and power in Kerala's Kudumbashree Programme. J Dev Stud. 2011;47(8):1261-80.

42. Sivaramakrishnan KC. Re-visioning Indian cities: the urban renewal Mission. New Delhi: SAGE India; 2011.

43. Federalism RR, Decentralisation U, Participation C. Econ Polit Wkly. 2007; 24(2):674-81.

44. Singh S. Citizens' Participation in urban governance: quest for transparency and accountability. Environ Urban ASIA. 2013;4(1):191-202.

45. Menon M, Kohli K. Environmental regulation in India moving "forward" in the old direction. Econ Polit Wkly. 2015;1(50):20-3.

46. Centre for Urban Equity CU. A methodology for local accessibility planning in Indian cities. 2014. Available from: https://cept.ac.in/UserFiles/File/CUE/ Research\%20Reports/A\%20Methodology\%20for\%20Local\%20Accessibility \%20Planning\%20in\%20Indian\%20Cities_Mahadevia\%20et\%20al.pdf

47. TERI. Enhancing public participation through effective functioning of Area Sabhas. Ministry of Urban Development, Govt of India; 2010. Report no:: 2009UD04. Available from: http://mohua.gov.in/upload/uploadfiles/files/ TERI_Sabhas_Report28.pdf

48. Public Participation Spectrum. IAP2 federation; 2014.

49. Desai R, Sanyal R. Introduction. In: Desai R, Sanyal R, editors. Urbanizing citizenship: contested spaces in Indian cities. New Delhi: Sage Publications India Pvt Ltd; 2012. p. 1-28.

50. Luckham R, Goetz AM, Kaldor M. Democratic institutions and politics in contexts of inequality, poverty and conflict: a conceptual framework. IDS; 2000 [cited 2019 Apr 14]. Available from: https://www.ids.ac.uk/files/ Wp104.pdf.

51. Heller P, Deliberation RV. Development. In: Heller P, Rao V, editors. Deliberation and development: rethinking the role of voice and collective action in unequal societies: World Bank; 2015. p. 1-26. Available from: http://hdl.handle.net/10986/22167.

52. Legacy C, Curtis C, Neuman M. Adapting the deliberative democracy "template" for planning practice. The town planning review. Liverpool. 2014; 85(3):319-40.

53. Christensen H, Grant B. Participatory Budgeting: The Next 'Big Thing' in Australian Local Government? In: Austaxpolicy: The Tax and Transfer Policy Blog; 2017. [cited 2018 Sep 15]. Available from: http://www.austaxpolicy. com/participatory-budgeting-next-big-thing-australian-local-government/.

54. Baburoglu ON, Goker GZ. Going large scale: the polling conference process for participatory constitution making in Turkey. Action Res. 2014;12(4):374-91.

55. Carolan E. Ireland's constitutional convention: behind the hype about citizen-led constitutional change. Int J Constit Law. 2015;13(3):733-48.

56. Bächtiger A, Dryzek JS, Mansbridge J, Warren ME. Introduction. In: Bachtiger A, Dryzek JS, Mansbridge J, Warren ME, editors. The Oxford handbook of deliberative democracy: Oxford University Press; 2018. p. $1-31$.

57. Catt H. Democracy in Practice. London: Routledge; 1999.

58. Fung A. Continuous Institutional Innovation and the Pragmatic Conception of Democracy. Polity. 2012;44(4):609-24.

59. Mansbridge JA. Minimalist definition of Deliberation. In: Heller P, Rao V, editors. Deliberation and development: rethinking the role of voice and collective action in unequal societies: The World Bank; 2015. p. 27-50. [cited 2018 Oct 28]. Available from: https://openknowledge.worldbank.org/handle/ 10986/22167.

60. Carson L, Hartz-Karp J. Adapting and combining deliberative designs: juries, polls, and forums. In: Gastil J, Levine P, editors. The deliberative democracy handbook: strategies for effective civic engagement in the twenty-first century. San Francisco: Jossey-Bass; 2005. p. 120-38.

61. Gastil J, Wright EO. Legislature by lot: envisioning Sortition within a bicameral system. Polit Soc. 2018;46(3):303-30.

62. Karpowitz C, Raphael C. Ideals of inclusion in Deliberation. J Public Deliberation. 2016;12(2). [cited 2019 Apr 17]. Available from: https://www. publicdeliberation.net/jpd/vol12/iss2/art3.

63. Levine P, Fung A, Gastil J. Future directions for public Deliberation. J Public Deliberation. 2005;1(1). [cited 2019 Apr 25]. Available from: https://www. publicdeliberation.net/jpd/vol1/iss1/art3.

64. Coelho M, Ratnoo V, Dellapiane S. Political economy of infrastructure in the UK. Institute for Government; 2014. Available from: https://www. instituteforgovernment.org.uk/publications/political-economyinfrastructure-uk

65. Baruah S. Mumbai's Mahul is a classic case of rehabilitation gone horribly wrong. The wire. 2017 [cited 2018 Oct 19]; Available from: https://thewire.in/featured/mumbais-mahul-classic-case-rehabilitationgone-horribly-wrong

66. The Hindu BusinessLine. Karnataka Govt drops Bengaluru steel flyover project: The Hindu BusinessLine; 2017. [cited 2018 Sep 18]. Available from: https://www.thehindubusinessline.com/news/national/karnataka-govt-dropsbengaluru-steel-flyover-project/article9567967.ece.

67. Jaipur Metro ill-conceived, Unviable: CAG. The times of India. 2018[cited 2018 Sep 18]; Available from: https://timesofindia.indiatimes.com/city/jaipur/ jaipur-metro-ill-conceived-unviable-cag/articleshow/65712118.cms

68. Johari A. Shut since November, with Rs 3,000 crore spent, what is the future of Mumbai's monorail project?. Scroll.in. 2018 [cited 2018 Sep 18]. Available from: https://scroll.in/article/886054/shut-since-november-and-with-rs-3000spent-on-it-what-is-the-future-of-mumbais-monorail-project

69. Antony A, Pandya D. Lavasa: Indian billionaire's paradise has now become a hell on earth: The Print; 2018. [cited 2018 Sep 6]. Available from: https:// theprint.in/featured/lavasa-indian-billionaires-paradise-has-now-become-ahell-on-earth/72043/.

70. Stephens JB, Berner M. Learning from your neighbor: the value of public Participation evaluation for public policy dispute resolution. J Public Deliberation. 2011:7(1):10.

71. Sastry T. Civil society, Indian elections and democracy today. Indian Institute of Management Bangalore; 2014 Jul Report No.: 465.

72. Ganguly S. Deliberating environmental policy in India: Participation and the role of advocacy. London: Routledge; 2015.

73. Kamath L, Burte $H$, Madhale A, King R. Pune: coalitions, contradictions, and unsteady transformation. In world resources institute; 2018 [cited 2018 Sep 1]. (Towards a More Equal City). Available from: https:// www.wri.org/wri-citiesforall/publication/pune-civil-society-coalitionspolicy-contradictions-and-unsteady

74. Bradbury-Huang $\mathrm{H}$. What is good action research?: why the resurgent interest? Action Res. 2010:8(1):93-109.

75. Trondsen $M$, Sandaunet $A-G$. The dual role of the action researcher. Eval Program Plann. 2009;32(1):13-20.

76. Menon S, Rapur S. Deliberative democracy and learning for sustainable mobility in Pune. In: Fadeeva ZLG, Chhokar K, editors. Academia and communities: engaging for change [internet]. Tokyo: UNU - IAS; 2018. Available from: https://collections.unu.edu/view/UNU:6601.

77. Centre for Environment Education, Curtin University, BN College of Architecture. Designing Street Spaces with People. Pune; 2013. [cited 2019 Apr 21]. Available from: http://ourpuneourbudget.in/democraticparticipation/.

78. Centre for Environment Education, Curtin University. Making our Participatory Budget in Pune more Effective . 2015 Available from: http:// ourpuneourbudget.in/democratic-participation/

79. Guide to the open budget questionnaire: an explanation of the questions and the response options [Internet]. International Budget Partnership; 2016. [cited 2019 Apr 21]. Available from: https://www.internationalbudget.org/ wp-content/uploads/open-budget-survey-2017-guide-and-questionnaireenglish.pdf.

80. Gadkari S. PMC goes WISE in budget, makes funding separations: Pune Mirror; 2016. [cited 2018 Sep 18]. Available from: https://punemirror. indiatimes.com/pune/civic/pmc-goes-wise-in-budget-makes-fundingseparations/articleshow/50723335.cms

81. Voter list management: survey on the quality of voter lists in Delhi [Internet]. Bengaluru: Janaagraha Centre for Citizenship and Democracy; 
2015. [cited 2018 Oct 28]. Available from: http:/www.janaagraha.org/files/ publications/Quality-of-Lists-Delhi-2015-MainReport.pdf.

82. Beauvais E, Baechtiger A. Taking the goals of Deliberation seriously: a differentiated view on equality and equity in deliberative designs and processes. J Public Deliberation. 2016;12(2). [cited 2018 Oct 28]. Available from: https://www.publicdeliberation.net/jpd/vol12/iss2/art2.

83. Gastil J. Toward a Deliberative Democracy. In: Political Communication and Deliberation. Thousand Oaks: SAGE Publications, Inc:; 2008. [cited 2019 Apr 17]. p. 280-90. Available from: http://sk.sagepub.com/books/politicalcommunication-and-deliberation/ $\mathrm{n} 10 . \mathrm{xml}$.

84. Li L, Ziwoya F, Black LW, Hartz-Karp J. Are they doing what they are supposed to do? In: Gastil J, Hartz-Karp J, Lubensky R, editors. The Australian citizens' parliament and the future of deliberative democracy: Penn State University Press; 2013. p. 190-203. [cited 2019 Apr 17]. Available from: http://www.sstor.org/stable/10.5325/j.ctt32b9zd.20.

85. Hardy M, Fisher K, Hartz-Karp J. The unsung heroes of a deliberative process. In: Carson L, Gastil J, Hartz-Karp J, Lubensky R, editors. The Australian citizens' parliament and the future of deliberative democracy: Penn State University Press; 2013. p. 177-89. [cited 2019 Apr 17]. Available from: http:// www.jstor.org/stable/10.5325/j.ctt32b9zd.19.

86. Barisione M. Framing a deliberation: deliberative democracy and the challenge of framing processes. J Public Deliberation. 2012;8(1):2.

87. Knobloch KR, Gastil J. Civic (re)socialisation: the educative effects of deliberative Participation. Politics. 2014:35(2):183-200.

88. Keruwala N. Participatory Budgeting in India -The Pune Experiment: Development Central; 2013. [cited 2019 Apr 21]. Available from: https:// developmentcentral.wordpress.com/2013/07/02/participatory-budgeting-inindia-the-pune-experiment/

89. Gastil J. Evidence from Oregon shows that citizens' initiative reviews can improve voters' decision-making about ballot measures [internet]: LSE US Centre; 2017. [cited 2018 Oct 28]. Available from: http://bit.ly/2ASPYZE.

Ready to submit your research? Choose BMC and benefit from:

- fast, convenient online submission

- thorough peer review by experienced researchers in your field

- rapid publication on acceptance

- support for research data, including large and complex data types

- gold Open Access which fosters wider collaboration and increased citations

- maximum visibility for your research: over $100 \mathrm{M}$ website views per year

At $\mathrm{BMC}$, research is always in progress.

Learn more biomedcentral.com/submissions 